\title{
THE EFFECTS OF THE EXPERIMENTAL INFECTION FROM A FOCUS OF TRANSMISSION OF Schistosoma mansoni IN A POPULATION OF Biomphalaria tenagophila (D'ORBIGNY, 1835) IN THE REGION OF "VALE DO RIBEIRA DE IGUAPE", BRAZIL
}

\author{
Marisa Cristina de Almeida GUIMARÃES(1), Cynthia MUNIZ(1), Fernanda Yoshika TAKAHASHI(1), Fernanda Pires OHLWEILER(1), \\ Toshie KAWANO(3) \& Delsio NATAL(2)
}

\begin{abstract}
SUMMARY
To observe the effects of the parasitic infection on the biology of B. tenagophila, field and laboratory populations of this mollusk from Itariri, in Vale do Ribeira, Brazil, were experimentally infected. Each mollusk received 10 miracidia of Schistosoma mansoni (SJ lineage) and was observed throughout the parasite's development. The biological variables were compared according to the criteria "group" and "infectious phase". The main damage caused by the parasitic infection manifested itself in reproduction, longevity and lesions on the shell of the mollusks in the patent phase. An infection rate of $58.8 \%$ was observed. Microanatomical study of the mollusk's digestive gland and ovotestis revealed the presence of evolving larval forms and cercariae. It was concluded that the effects of the parasitic infection on both populations were moderate, despite the low survival rate of the infected mollusks, the damage did not prevent either reproduction or the elimination of cercariae, which continued for a long time.
\end{abstract}

KEYWORDS: Schistosoma mansoni; Parasitic infection; Biomphalaria tenagophila.

\section{INTRODUCTION}

Schistosomiasis is one of the most widespread parasitic diseases in tropical countries; according to the WHO, seventy-four countries are considered endemic ${ }^{4,23}$. The state of São Paulo has a low endemicity, and the main regions for transmission in the state are: Vale do Paraíba, Vale do Ribeira de Iguape and Baixada Santista. Today, coastal regions in the north of the state and the "Great São Paulo" and Campinas are also considered as endemic ${ }^{3,20,21}$.

Cases of schistosomiasis have been reported in the municipality of Itariri, in the Vale do Ribeira region, since $1953^{18}$. The region has a great variety of bodies of water, as well as ditches and channels that were built mainly for the banana farming industry in Itariri and nearby municipalities, where the intermediate mollusk hosts are found. Biomphalaria tenagophila is the species responsible for transmitting Schistosoma mansoni in the region ${ }^{18,20}$

In the 1980 s the municipality had a great number of cases of the disease until effective control measures to reduce its prevalence were implemented in both Itariri and Pedro de Toledo, which also had a high incidence of schistosomiasis ${ }^{12,13,18}$. In spite of advances, 290 cases were recorded in Itariri in the ten-year period from 1998 to 2008, making this municipality have the highest notification rate in the region ${ }^{3}$.
The Schistosomiasis Control Program ${ }^{19}$ (PCE in Portuguese) advocates continuous integrated control and surveillance measures. One such measure is mollusk control, which is an essential strategy. The epidemiologic importance of the Itariri region can thus be seen. In the light of this epidemiological importance, the aim of this study was to investigate the effects of parasitic infection by S. mansoni on the intermediate mollusk host in the region.

It is known from the available knowledge on host-parasite interaction that various degrees of virulence can be observed in the mollusk host and that during the course of its cycle, the parasite develops escape strategies to counteract the mollusk's responses, such as the production of antigens on the surface of its body, similar to those produced by the host to confuse the mollusk ${ }^{1,9,17}$.

In addition, various studies have found alterations in organs, morphology and physiology of the intermediate host, caused by the presence of trematode larvae in its digestive gland and ovotestis, and as a result its reproductive pattern was also affected ${ }^{2,5,7,16}$. Various phenomena are frequently observed, from a reduction in fecundity to partial or total suppression of the production of gametes, known as parasitic castration. In B. glabrata, for instance, castration can be caused by sporocysts of $S$. mansoni, resulting in the suppression of egg production or the production of malformed eggs. Parasitic infections can also affect mollusk growth and survival ${ }^{1,2,10,11,17,22}$.

(1) Superintendency for the Control of Endemic Diseases/SUCEN, São Paulo, SP, Brazil.

(2) Faculty of Public Health, USP, São Paulo, SP, Brazil.

(3) Parasitology Laboratory, Butantan Institute, São Paulo, SP, Brazil.

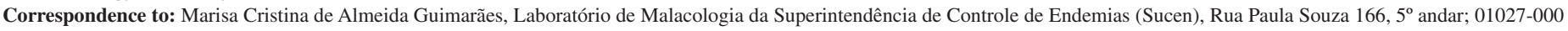
São Paulo, SP, Brasil. Tel: +55 113311 1175. E-mail: marisaag@sucen.sp.gov.br 


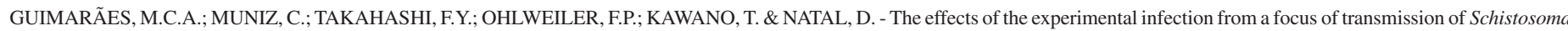
mansoni in a population of Biomphalaria tenagophila (D'Orbigny, 1835) in the region of "Vale do Ribeira de Iguape", Brazil. Rev. Inst. Med. Trop. São Paulo, 52(2):101-5, 2010.

In the light of these observations, we decided to investigate the effects of this parasitic infection on the biology of Biomphalaria tenagophila from a schistosomiasis focus in Itariri, a municipality in Vale do Ribeira, which is a risk area with a long history of transmission of the disease in the state of Sao Paulo.

\section{METHODOLOGY}

Study population: Biomphalaria tenagophila from Ana Dias, Itariri, São Paulo.

Geographical location of Itariri: latitude $24^{\circ} 17^{\prime} 21^{\prime \prime} \mathrm{S}$; longitude $47^{\circ} 10^{\prime} 28^{\prime \prime} \mathrm{W}$; altitude 55 meters.

Collection area: irrigation ditch in a banana-growing area that is a traditional focus for transmission of Schistosoma mansoni, also referred to as the "Sabiá Focus" (Fig. 1) by the regional division of SUCEN (Superintendency for the Control of Endemic Diseases).

Parasite: Schistosoma mansoni, SJ lineage, from São José dos Campos, São Paulo.

\section{B. tenagophila populations:}

1. field population;

2. laboratory population (P generation).

Field Population: Initially, 150 mollusks were collected from the irrigation ditch (Fig. 1). These were kept under observation in experimental conditions during four weeks to select specimens that had recently acquired sexual maturity and were free of infection. The final sample obtained consisted of $\mathbf{1 3 9}$ mollusks, made up of 11 experimental groups with six, seven or eight mollusks, giving a total of 71, and $\mathbf{1 0}$ control groups with six or seven mollusks, giving a total of 68 .

Maintenance of the specimens in the laboratory: each snail was kept in $130 \mathrm{~mL}$ of water and fed with fresh lettuce.

Biological variables observed: Egg capsules, eggs, hatched eggs, number of dead individuals and length of time cercariae were eliminated (weeks/days).

Parameters analyzed: Mollusk fecundity ${ }^{\mathrm{a}}$, fertility ${ }^{\mathrm{b}}$ and survival and the duration of the pre-patent and patent phases.

Laboratory population: Made up of a sample containing 69 mollusks (P generation) from the laboratory divided into experimental groups (34 individuals in total) and control groups (35 individuals in total). The mollusks were observed individually and reproduced by self-fertilization.

Biological variables observed: Egg capsules, eggs, shell size in millimeters, number of dead individuals and length of time during which cercariae were eliminated.

Parameters analyzed: Mollusk fecundity, size and survival and the duration of the pre-patent and patent phases.
Statistical analysis was carried out with assistance of the SPSS (Statistical Package for Social Sciences) software - version 16. Data were compared between the two groups (experimental and control) and the infection phases (pre-patent and patent). Student's t test was used with a 5\% significance level for the variables fecundity, fertility and survival in the field population, and for fecundity, size and survival in the laboratory population.

Experimental-infection procedures for both populations: Each mollusk was placed in a well of a cell culture plate with four $\mathrm{mL}$ of filtered water and ten S. mansoni miracidia, where it was left for two hours under artificial light to stimulate penetration of the mollusk's integument by the miracidiae. Following this, the snails were returned to their aquaria, and those that were infected were observed from the $35^{\text {th }}$ day of infection.

Microanatomical observations: Five specimens of B. tenagophila from the laboratory population that had been infected for 35 days were used, and their digestive glands and ovotestes were removed for histological examination. Longitudinal histological sections seven microns thickness were then prepared. Gomori's Trichrome stain ${ }^{8}$ was used, and images of the slides were recorded using an optical microscope at 100X, 200X and 400X magnification.

\section{RESULTS}

1. Biomphalaria tenagophila (field population): Mean fecundity measurements in both groups fell in the patent phase, and the mean value for the experimental groups was lower than that for the control groups $(p=0.000)$ (Table 1).

Mean fertility measurements in the patent phase were lower than in the previous phase, and statistically significant differences were observed between the groups $(p=0.003)$ (Table 1$)$.

No significant difference in the mean number of mollusks that survived the pre-patent phase was found between the experimental and control groups $(p=0.08)$. In the patent phase, the mean number of mollusks that survived was lower than the corresponding number for the control groups; this difference was statistically significant $(p=0.000)$ (Table 1).

The pre-patent and patent phases lasted 35 and 56 days, respectively.

2. Biomphalaria tenagophila (laboratory population): No significant differences in mean fecundity and size (Table 2 ) between the groups were observed in the respective infection phases $(p>0.05)$.

The mean survival rate of the mollusks was lower in the patent phase, and a statistically significant difference was found between the control and experimental groups $(\mathrm{p}=0.000)$ (Table 2$)$.

The pre-patent and patent phases lasted 49 and 119 days, respectively.

The infection rate was $58.8 \%$.

3. Microanatomical examination of tissues infected by parasites revealed the presence of $S$. mansoni larvae in various stages of evolution: secondary sporocysts with clusters of germinative cells (Figs. 2, 5); cercariae in the process of forming and outside the digestive gland (Fig.4); and an (immunological) cellular reaction around a degenerating larva (Fig 3).

\footnotetext{
${ }^{a}$ Fecundity is expressed as the number of eggs per egg capsule ${ }^{b}$ Fertility is expressed as number of hatched eggs per number of eggs.
} 


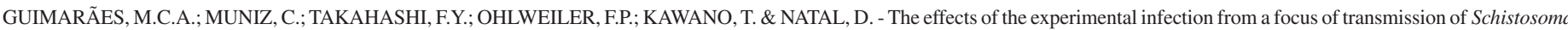
mansoni in a population of Biomphalaria tenagophila (D'Orbigny, 1835) in the region of "Vale do Ribeira de Iguape", Brazil. Rev. Inst. Med. Trop. São Paulo, 52(2):101-5, 2010.

\section{DISCUSSION}

It is common for host mollusks to modify their biological characteristics to make up for the negative effects of parasitic infections.

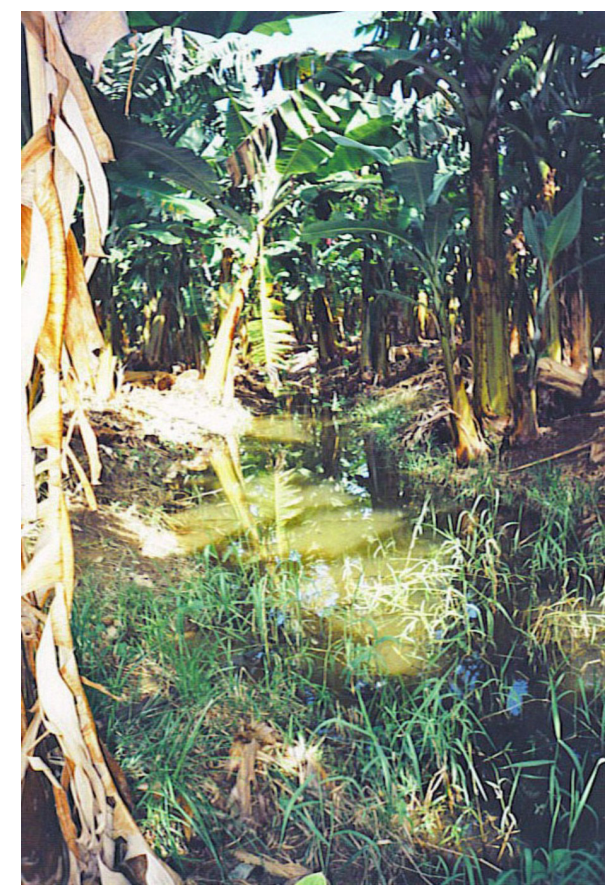

Fig. 1 - Ditch-Sabiá Focus in Ana Dias, Itariri.
For example, they can alter their reproductive potential to increase temporarily spawning in response to the reduced reproduction expected when the host is suffering from the effects of parasitism ${ }^{1,10,22}$.
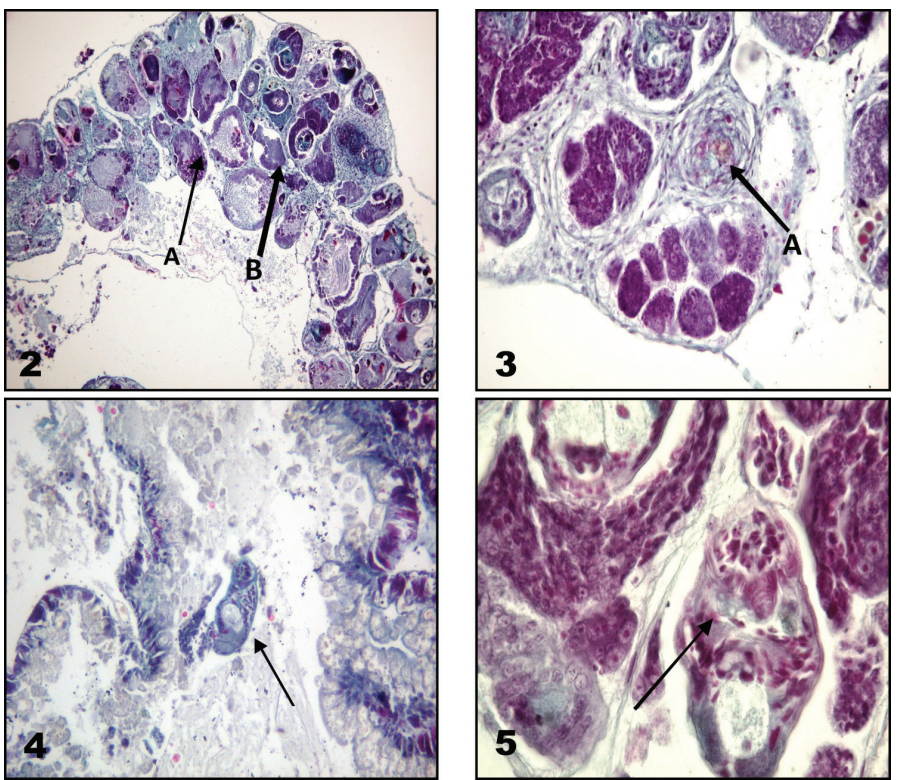

Biomphalaria tenagophila (d'Orbigny, 1835) - laboratory population. Fig. 2: (A) Ovotestis with secondary sporocysts, 100X; (B) Cercaria in the process of forming, 100X. Fig. 3: (A) Ovotestis with a degenerating larva containing yellow pigment and a cellular reaction around it, 200X. Fig. 4: A cercaria outside the digestive gland, 200X. Fig. 5: A secondary sporocyst with clusters of germinative cells, $\mathbf{4 0 0 X}$.

Table 1

Mean fecundity, fertility and survival of mollusks in the field population by group and infection phase

\begin{tabular}{|c|c|c|c|c|c|c|c|c|c|c|c|c|}
\hline & \multicolumn{4}{|c|}{ *Fecundity } & \multicolumn{4}{|c|}{ *Fertility } & \multicolumn{4}{|c|}{ *Survival } \\
\hline & \multicolumn{2}{|c|}{ Pre-patent } & \multicolumn{2}{|c|}{ Patent } & \multicolumn{2}{|c|}{ Pre-patent } & \multicolumn{2}{|c|}{ Patent } & \multicolumn{2}{|c|}{ Pre-patent } & \multicolumn{2}{|c|}{ Patent } \\
\hline & eg & $\mathrm{cg}$ & eg & $\mathrm{cg}$ & eg & $\mathrm{cg}$ & eg & $\mathrm{cg}$ & eg & $\mathrm{cg}$ & eg & $\mathrm{cg}$ \\
\hline Mean & 7.63 & 6.95 & 1.74 & 4.72 & 79.93 & 68.40 & 15.44 & 35.81 & 61.83 & 65.16 & 17.60 & 47.70 \\
\hline S.E. & 0.25 & 0.38 & 0.31 & 0.32 & 1.43 & 3.35 & 3.36 & 6.72 & 1.49 & 0.83 & 3.79 & 2.22 \\
\hline$p$ value & \multicolumn{2}{|c|}{$p=0.137$} & \multicolumn{2}{|c|}{$p=0.000$} & \multicolumn{2}{|c|}{$p=0.001$} & \multicolumn{2}{|c|}{$p=0.003$} & \multicolumn{2}{|c|}{$p=0.080$} & \multicolumn{2}{|c|}{$p=0.000$} \\
\hline
\end{tabular}

*Student's t test $; \mathrm{eg}=$ experimental group; $\mathrm{cg}=$ control group.

Table 2

Mean fecundity, size and survival of mollusks in the laboratory population by group and infection phase

\begin{tabular}{|c|c|c|c|c|c|c|c|c|c|c|c|c|}
\hline & \multicolumn{4}{|c|}{ *Fecundity } & \multicolumn{4}{|c|}{ *Size $(\mathrm{mm})$} & \multicolumn{4}{|c|}{ *Survival } \\
\hline & \multicolumn{2}{|c|}{ Pre-patent } & \multicolumn{2}{|c|}{ Patent } & \multicolumn{2}{|c|}{ Pre-patent } & \multicolumn{2}{|c|}{ Patent } & \multicolumn{2}{|c|}{ Pre-patent } & \multicolumn{2}{|c|}{ Patent } \\
\hline & eg & $\mathrm{cg}$ & eg & $\mathrm{cg}$ & eg & $\mathrm{cg}$ & eg & $\mathrm{cg}$ & eg & $\mathrm{cg}$ & eg & $\mathrm{cg}$ \\
\hline Mean & 0.10 & 0.25 & 1.25 & 1.36 & 5.33 & 5.51 & 7.81 & 8.07 & 32.77 & 33.66 & 18.00 & 25.61 \\
\hline S.E. & 0.03 & 0.06 & 0.16 & 0.13 & 0.23 & 0.22 & 0.19 & 0.18 & 0.46 & 0.66 & 1.47 & 0.51 \\
\hline$p$ value & \multicolumn{2}{|c|}{$p=0.065$} & \multicolumn{2}{|c|}{$p=0.599$} & \multicolumn{2}{|c|}{$p=0.597$} & \multicolumn{2}{|c|}{$p=0.321$} & \multicolumn{2}{|c|}{$p=0.290$} & \multicolumn{2}{|c|}{$p=0.000$} \\
\hline
\end{tabular}

*Student's t test; eg = experimental group; $\mathrm{cg}=$ control group. 


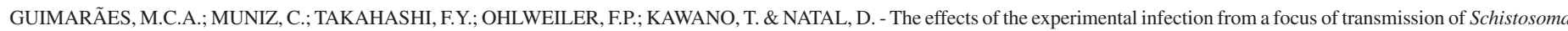
mansoni in a population of Biomphalaria tenagophila (D'Orbigny, 1835) in the region of "Vale do Ribeira de Iguape", Brazil. Rev. Inst. Med. Trop. São Paulo, 52(2):101-5, 2010.

In the present study the mollusks infected with parasites were found to display less reproductive activity than the control mollusks (Tables 1,2). The reproductive performance of the field population was at its lowest during the patent phase of the infection. This pattern supports the data in the literature, which indicate that there is a greater investment in reproduction during the first weeks of infection (the pre-patent phase) and that reproduction declines until castration of the intermediate host occurs ${ }^{1,5,10,11}$.

Observation of the shells of the infected mollusks is important as damage, such as fragile and broken shells and shells with distorted coiling, were found in these from the patent period onwards. Studies have shown that shell lesions are caused by a lack of calcification, as a result of the diversion of essential nutrients to the parasites to the detriment of the host mollusk $^{9}$. No significant difference in the average size of the mollusks was observed between the experimental and control groups $(p>0.05)$.

The variable "mortality" was found to behave similarly in both populations (field and laboratory): both suffered a greater decline in numbers in the patent phase of the infection (Tables 1,2). Mean survival was undoubtedly lower for the experimental group, a result compatible with the findings reported by MALEK \& $\mathrm{CHENG}^{9}$ who observed the effects of infection on the longevity of host mollusks and its relationship with acute changes in tissues infected by trematode parasites.

The findings in relation to the length of the pre-patent and patent phases showed that the parasites developed faster in the field population. The laboratory population had a long patent phase - as long as 119 days (17 weeks) for the few individuals that survived infection. This finding is similar to the results reported by FIGUEIREDO et al. ${ }^{6}$, who observed a patent phase for B. tenagophila (also from Ana Dias) that lasted 104 days (14.8 weeks). The main implication of a long patent period is the maintenance of an active schistosomiasis focus.

The infection rate recorded for the experimental population was $58.8 \%$, very close to the result reported by FIGUEIREDO et al. ${ }^{6}$, who found an infection rate of $60.0 \%$ for B. tenagophila from Itariri. PARAENSE \& CORRÊA ${ }^{15}$ also experimentally infected various $B$. tenagophila populations from 18 different locations in Brazil and found infection rates varying between $0.0 \%$ and $91.5 \%$, the latter figure being for a $B$. tenagophila population that was also from Itariri.

Information about the natural infection rate for B. tenagophila was obtained from data"gathered over the last five years for $B$. tenagophila from Itariri, which revealed a mean infection rate of $2.67 \%$. MUNIZ ${ }^{14}$ recently found natural infection rates of $0.86 \%$ for $B$. tenagophila from the Palmeira focus and $1.51 \%$ for the population in the Sabiá focus, both of which are in the Ana Dias district, in Itariri, where many bodies of water contain mollusks infected by parasites ${ }^{7,14}$.

Microanatomical observations of the mollusks revealed the presence of a number of developing larval forms, phagocytic reactions and the presence of cercariae in the ovotestes.

It can be concluded that the effects of the parasitic infection studied here on both field and laboratory populations from Ana Dias were moderate as, despite the low survival rate of the mollusks, the damage caused did not prevent reproduction or the elimination of cercariae for a longer period. This shows the great ability of these populations to adjust their biological patterns to survive the adverse effects of parasitism, a characteristic that may be the key to understanding the circumstances that lead to the survival of foci with active transmission of S. mansoni, such as the Sabiá focus in Itariri.

\section{RESUMO}

\section{Efeitos da infecção experimental de um foco de transmissão de Schistosoma mansoni em população de Biomphalaria tenagophila (D'Orbigny, 1835) na região do Vale do Ribeira de Iguape, Brasil}

Com objetivo de observar os efeitos da infecção parasitária na biologia de $B$. tenagophila, foram realizadas infecções experimentais em populações de campo e laboratório, ambas procedentes de Itariri, Vale do Ribeira, Brasil. Cada molusco recebeu 10 miracídios de Schistosoma mansoni (linhagem SJ), sendo observado durante o desenvolvimento dos parasitos. As variáveis biológicas foram comparadas segundo os critérios "grupo" e "fase de infecção". Os principais danos decorrentes do parasitismo se manifestaram na reprodução, na longevidade e em lesões na concha dos moluscos na fase patente. Foi encontrada uma taxa de infecção de 58,8\%. O estudo microanatômico da glândula digestiva e do ovoteste do molusco revelou a presença de formas larvárias em evolução e cercárias. Concluiu-se que os efeitos da infecção parasitária, sobre as duas populações, foram moderados, uma vez que os danos não impediram a reprodução e a eliminação de cercárias que se manteve por um longo período, apesar da baixa sobrevivência dos moluscos parasitados.

\section{ACKNOWLEDGMENT}

Patrícia Miyasato, Carlos Nascimento and Cristina Chagas.

\section{REFERENCES}

1. Agnew P, Koella JC, Michalakis Y. Host life history responses to parasitism. Microbes Infect. 2000;2:891-6

2. Blair L, Webster JP. The impact of parasite pressure on the reproductive fitness. In $8^{\text {th }}$ International Symposium on Schistosomiasis, Recife- Pe, Brazil, 2001; Resumos. ST4-48.

3. Boletim Epidemiológico Paulista - BEPA. Centro de Vigilância Epidemiológica "Prof. Alexandre Vranjac”. v.6 (supl. 6), maio 2009. São Paulo: CCD/SES-SP; 2009

4. Chitsulo L, Engels D, Montresor A, Savioli L. The global status of schistosomiasis and control. Acta Trop. 2000;77:41-51.

5. Faro MJ, Maldonado A, Corrêa LR. Estudo da biologia reprodutiva de Biomphalaria glabrata infectada por Schistosoma mansoni e sua relação com a castração parasitária. In: XXI Encontro Brasileiro de Malacologia, Rio de Janeiro, Brasil; 2009. Resumos. p. 347.

6. Figueiredo AC, Dias LCS, Marques LHF. Biological and morphological characteristics of Schistosoma mansoni from Ribeira Valley, State of São Paulo, Brazil. I. Susceptibility of Biomphalaria tenagophila snail to sympatric S. mansoni strain. Rev Inst. Med. Trop. Sao Paulo. 1992;34:199-203. 
GUIMARÃES, M.C.A.; MUNIZ, C.; TAKAHASHI, F.Y.; OHLWEILER, F.P.; KAWANO, T. \& NATAL, D. - The effects of the experimental infection from a focus of transmission of Schistosoma mansoni in a population of Biomphalaria tenagophila (D'Orbigny, 1835) in the region of “Vale do Ribeira de Iguape”, Brazil. Rev. Inst. Med. Trop. São Paulo, 52(2):101-5, 2010.

7. Guimarães MCA. Avaliação do controle e vigilância do hospedeiro intermediário do Schistosoma mansoni, no Vale do Ribeira, e observações do seu parasitismo. [Tese] São Paulo: Faculdade de Saúde Pública da Universidade de São Paulo; 2008.

8. Maia V. Técnica histológica. $2^{\text {nd }}$ ed. São Paulo: Atheneu; 1979.

9. Malek EA, Cheng TC. Medical and economic malacologic. New York: Academic Press; 1974.

10. Minchella DJ, Loverde PT. A cost of increased reproductive effort in the snail Biomphalaria glabrata. Am Naturalist. 1981;188:876-81.

11. Minchella, DJ. Host life-history variation in response to parasitism. Parasitology. 1985;90:205-16

12. Marçal Júnior O, Patucci RMJ, Dias LCS, Hotta LK, Etzel A. Schistosomiasis mansoni in area of low transmission. I. Impact of control measures. Rev. Inst. Med. Trop. Sao Paulo. 1991;33:83-90.

13. Marçal Júnior O, Hotta LK, Patucci RMJ, Glasser CM, Dias LCS. Schistosomiasis mansoni in area of low transmission. II. Risk factors for infection. Rev. Inst. Med. Trop. Sao Paulo. 1993;35:331-5.

14. Muniz C. Levantamento da malacofauna limnica e aspectos ecológicos de focos de esquistossomose em Ana Dias, Vale do Ribeira, SP. [Dissertação]. São Paulo; Faculdade de Saúde Pública da Universidade de São Paulo; 2007.

15. Paraense WL, Corrêa LR. Differential susceptibility of Biomphalaria tenagophila populations to infection with a strain of Schistosoma mansoni. J. Parasitol. 1978;64:822-6.
16 Pearson EJ, Cheng TC. Studies on parasitic castration: ocurrence of a gametogenesisinhibiting factor in extract of Zoogonus lasius (trematoda). J Invertebr Pathol.1985;46:239-46.

17. Sorensen RE, Minchella DJ. Snail-trematodeo life history interaction: past trends and future directions. Parasitology. 2001;123:S3-S18.

18. SUCEN. Superintendência de Controle de Endemias. Relatório $\mathrm{II}^{\circ}$ Encontro sobre Esquistossomose. São Paulo; 1982.

19. SUCEN. Superintendência de Controle de Endemias. Programa de Controle da Esquistossomose. São Paulo: Secretaria de Estado da Saúde; 1989.

20. SUCEN. Superintendência de Controle de Endemias. Relatório de Avaliação do Programa da Esquistossomose no Estado de São Paulo 1981-1992. São Paulo; 1994.

21. SUCEN. Superintendência de Controle de Endemias. Relatório de Avaliação do Programa da Esquistossomose no Estado de São Paulo de 1990- 2002. São Paulo; 2004

22. Thornhill JA, Jones JT, Kusel JR. Increased oviposition and growth in immature Biomphalaria glabrata after exposure to Schistosoma mansoni. Parasitology 1986;93:443-50

23. WHO/World Health Organization. Schistosomiasis 2007. [cited 2009 Aug 10]. Available from: http://www.who.int/mediacentre/factsheets/fs115/en/print.html.

Received: 5 May 2009

Accepted: 20 January 2010 